\author{
Bartłomiej Łuć \\ ORCID 0000-0003-0798-675X \\ University of Lodz \\ Institute of Urban Geography and Tourism Studies \\ bartlomiej.luc@op.pl
}

\title{
THE TOURISM SPACE OF BARLINEK IN THE CONTEXT OF SPATIAL MODELS
}

\begin{abstract}
This article describes the tourism space of Barlinek in the context of a spatial model. On the basis of field studies and analyses of tourism attractions and elements of tourism development, the author has compared and adapted the models developed by S. LISZEWSKI (1995) and B. WŁODARCZYK (2011). Moreover the author has developed an extended SWOT analysis of Barlinek's tourism space.
\end{abstract}

Keywords: Barlinek, tourism space, model, tourism infrastructure, tourism attraction.

\section{INTRODUCTION}

Tourism space, and various phenomena associated with it, are the subject much academic research by geographers as well as sociologists and economists. Discussion on tourism space is wide and quite complicated as it changes rapidly through both natural and human factors (WŁODARCZYK 2011).

One of the first definitions was developed by J.M. MiOSSEC (1976) more than 40 years ago. In his opinion it was a space located only on the edge of a built-up area in places where the possibility of overcoming distance makes it possible to create tourism demand. A. JACKOWSKI and J. WARSZYŃSKA (1976) recognized that tourism space is that part of geographical space in which tourism phenomena occur. A few years later W.C. HuSBANDS (1983) stated that tourism space includes the subsystem of tourism accommodation and the links between both systems. M. STALSKI (1984), as a basic element of tourism space, recognized the possibility of providing tourism and recreational services and programs, as well as the chance to rest. Over ten years later, S. LISZEWSKI (1995) recognized that tourism space is a functionally distinct part of the entire geographical space created by both natural elements and factors related to human activity. One of the latest definitions was developed by B. WŁODARCZYK (2009). In his opinion the basic factor that allows a given space to be classified as tourism space is the occurrence of tourism. Another additional condition is the functioning of elements of tourism development. These two components determine the size and type of a given tourism space. Similar to S. LISZEWSKI (1995), he considered it part of general geographical space.

This article widens the considerations and issues that the author addressed in his master's thesis: 'The Tourism Attractiveness of Barlinek', written in 2018. The main purpose is to classify the tourism space of Barlinek by type based on the models of tourism space developed by S. LISZEWSKI (1995) and B. WŁODARCZYK (2011). In addition, the author has attempted to develop an extended SWOT analysis of Barlinek's tourism space.

Field research was carried out in late July and early August 2017. The spatial range of the research was covered by the administrative boundaries of the town of Barlinek and the place of permament residence of the tourists surveyed. The research method used by the author were mainly questionnaire surveys carried out with incidentally met residents and tourists, as well as an inventory of tourism values and individual elements of tourism development. In total 216 residents of Barlinek and 200 tourists took part in the survey. The research was carried out mainly in the vicinity of the town market and the promenade by Lake Barlinek. Moreover, based on the field inventory and personal observations, the author developed an extended SWOT analysis of Barlinek's tourism space. 


\section{DESCRIPTION OF BARLINEK}

Barlinek is a town located in the north-western part of Poland, in the southern part of the West Pomeranian Voivodeship, in Mysliborsk powiat. It is the seat of the urban-rural commune of Barlinek (CZOPEK \& PIESZCZACHOWICZ 2001). In 2017 about 15,000 inhabitants lived there, which made it the most highly populated town in the powiat. The area of the town is about $17 \mathrm{~km}^{2}$.

Geographically, it is located in the Mysliborz Lake District and on the Gorzow Plain, along the Mlynowka and Plonia Rivers and Lakes Barlineckie, Chmielowe and Uklejno. Nearly $50 \%$ of its area is the Barlinek Forest strictly protected in the form of the BarlinekGorzow Landscape Park (PRZYBYLSKI \& SKAZIŃSKI 2014). This is a large forest complex spreading over a sandur plain which was deposited post-glacially around 12,000 years ago (KONDRACKI 1998). About $3 \%$ of the town's area is made up of lakes, of which Barlineckie is the largest (about 272 ha). To the north, the town borders the Plonia Valley, famous for picturesque gullies and clumps of trees and shrubs (PRZYBYLSKI \& SKAZIŃSKI 2014).

Barlinek's development was largely determined by very favorable natural conditions in the form of the immediate vicinity of the lake and forest which provided food and security. The first traces of settlement are dated to the neolithic and the later bronze and iron age periods (MIELCAREK \& PRZYBYLSKI 2009). In the Middle Ages, the local area was the part of the Piast state (MIELCAREK 2006). The year 1278 is recognized as the official date of its foundation when the Brandenburg margraves published the town's charter in Gorzow (PRZYBYLSKI \& SKAZIŃSKI 2014). The worst period in Barlinek's history was the turn of the 17th century, when the town was devasted by numerous fires. Serious destruction had also occurred during the Thirty Years' War with reconstructions only completed at the end of the $18^{\text {th }}$ century (MIELCAREK 2006). The turn of the $20^{\text {th }}$ century was the time of its greatest prosperity. At that time Barlinek was considered a well-known German tourism resort, called the 'Pearl of the New March'. Currently, the town is promoted as the 'European capital of nordic walking'. In addition, at a national level, it is famous for its timber industry and the production of floor panels (so-called Barlinek boards).

\section{ELEMENTS SHAPING THE TOURISM SPACE OF BARLINEK}

According to B. WŁODARCZYK (2011), the elements which create tourism space include:

- natural heritage,

- cultural heritage (tangible and intangible),
- tourism infrastructure (accommodation, gastronomy, paratourism base, transport infrastructure),

- people (tourists, organisers and managers of tourism space).

The natural heritage of Barlinek is created first of all by Lake Barlineckie which, in the opinion of the majority of inhabitants and tourists, is the main attraction of the town. Currently, the part of its shoreline located within the town's administrative boundaries is about $5.6 \mathrm{~km}$, with an area of water of about $162 \mathrm{ha}$. Further lakes are those of Chmielowe and Uklejno. An important element is Barlinek Forest protected as part of the Barlinek-Gorzow Landscape Park. Among the elements of natural heritage, areas of urban greenery should be taken into account among which Emanuel Lasker Park and monuments of nature, including the równoleżnikowa lime tree, are the best known. The natural heritage is also created by its climate characterized by higher than average annual temperatures (above $8.5^{\circ} \mathrm{C}$ ) and a low precipitation of about $550 \mathrm{~mm}$ per year (BORYCZKA \& STOPABORYCZKA 2005).

Barlinek's cultural heritage is created most of all by its monuments. Due to its turbulent history, the preserved buildings come mostly from the Middle Ages and the turn of the $20^{\text {th }}$ century. From the first era, the town square, the church of the Blessed Virgin Mary and the remains of defensive walls should be mentioned, while at the turn of the $20^{\text {th }}$ century, among others, the historic bathing resort of Pod Sosnami and the church of St. Boniface. An important role is also played by intangible elements of cultural heritage and there are many cultural and sports events organized here. Two important figures are Romana Kaszczyc a writer of fairytales and legends and Emanuel Lasker, a world chess champion from the interwar period (HOFFMAN 2014). These are in many cases the basic motive for tourist features: examples are the 'Emanuel Lasker Trail', the annual election of the 'Queen of Barlinek Forest' and the 'Blue Legend Trail' connected directly to the fairy tale written by Romana Kaszczyc.

One of the basic elements of tourism infrastructure is the accommodation base. Data obtained at the Tourism Information Center showed that in Barlinek, not including private accommodation, there are 18 facilities while in total, in July 2017, the town had about 1100 beds. These were of all the types specified in the Act of 29 August 1997 on tourism services excluding motels. The most famous are the 3-star Alma Spa hotel and the Pod Sosnami guesthouse, which is the oldest in the town.

An important element of the tourism infrastructure is the gastronomic base. Based on data obtained at the Tourism Information Center in July 2017 Barlinek had 
over 20 catering facilities, mostly restaurants and canteens. The most famous are the Stara Galeria resturant, known for organizing many cultural events, and the Brusilewicz ice cream parlor attracting crowds of customers from nearby towns.

Another element is the paratourism base, designed to meet the socio-economic needs of both tourists and inhabitants (KACZMAREK, STASIAK \& WŁODARCZYK 2010). In the case of Barlinek, this base is created by primarily of sports and recreation facilities with the most characteristic being bathing and rental of water equipment associated with Lake Barlineckie. A wellknown site is the Bronisław Bagiński Stadium. In addition, the Barlinek paratourism base has shops and banks as well as hygienic and sanitary facilities like a hospital, a medical clinic and pharmacies. The number is so large that it can completely satisfy the needs of tourists and inhabitants.

The communication infrastructure is equally important and in most cases divides into external and internal (KUREK \& MIKA 2008). The external is mainly based on the routes of two provincial roads (nos 151 and 156) and several smaller roads of powiat and communal importance. The big disadvantage is the lack of a railway connection and the negligible number of bus connections with nearby towns. The internal communication infrastructure is much better and its most important elements are numerous tourism trails, both for hiking and cycling. The functioning of nordic walking routes is also significant with the most interesting routes include the 'Water Trail' by Lake Barlineckie and the 'Blue Legend Trail' based on the tale by Romana Kaszczyc (Aktywny wypoczynek... 2017). However, the small number of car parks is a big problem, which makes it difficult to get to many places, such as the historic bathing resort of Pod Sosnami and the town square.

A very important element of tourism space are people. One group are the inhabitants who are responsible for the organization and management of a given space. In the case of Barlinek, the most important entity is the Barlinek Culture Center which directly supervises the activity of the Tourism Information Center and the Regional Museum. These instititions deal with both strategies for tourism development and promotion while also overseeing the development of tourism infrastructure. A slightly smaller role is played by local government as well as by accommodation, gastronomic, and sports and recreation facilities.

The second important group are the tourists who come to Barlinek. During the research, the author managed to obtain statistics about the volume of tourism in 2012-2016 (Fig. 1). These data were prepared by the staff of the Tourism Information Center on the basis of survey questionnaires filled in by individual accommodation facilities. The average volume in 2012-2016 amounted to about 13,000 tourists, however, most tourists visited Barlinek in 2013 (almost $18,000)$.

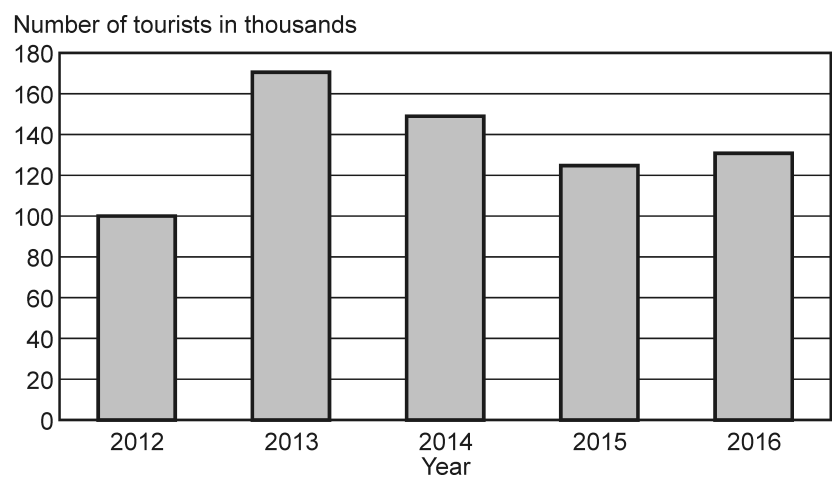

Fig. 1. Tourism in Barlinek: 2012-2016 Source: author, based on data obtained from the Tourism Information Center in Barlinek
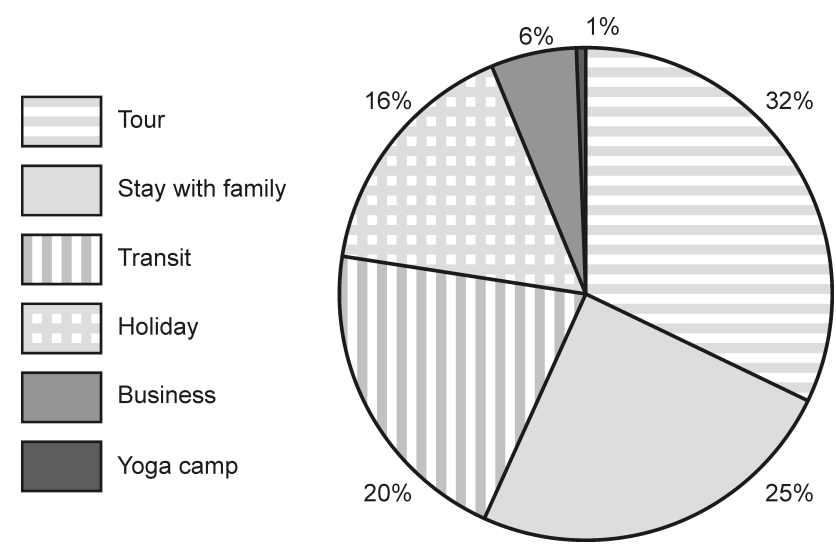

Fig. 2. Types of tourism stay in Barlinek Source: author, based on surveys conducted in July 2017

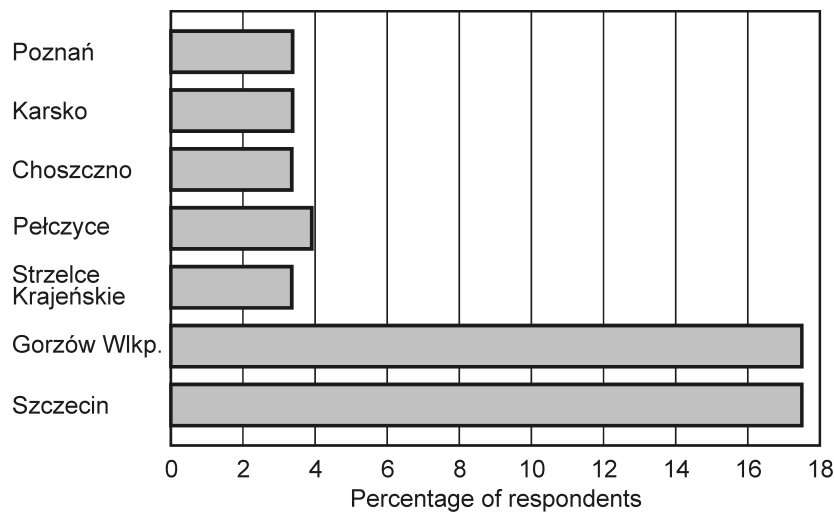

Fig. 3. The percentage of respondents from the most frequent national locations

Source: author, based on surveys conducted in July 2017

Survey research on tourists shows that Barlinek is a destination mainly for people from nearby West Pomeranian and Lubuskie voivodeships, those having 
a family or friends there, and tourists from Germany and Scandinavia, in particular from Denmark (Figs 2-4).

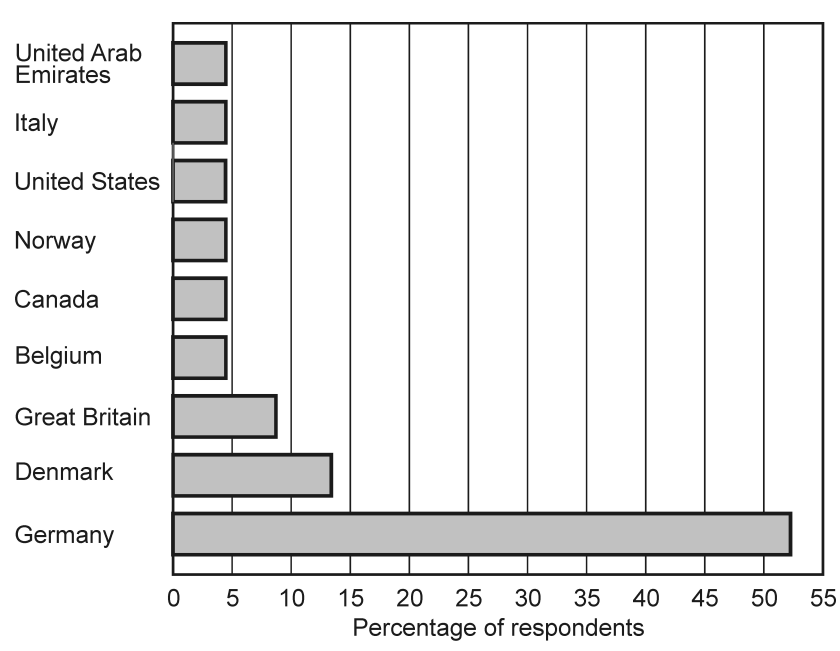

Fig. 4. Countries of origin of surveyed tourists Source: author, based on surveys conducted in July 2017

\section{THE TOURISM SPACE OF BARLINEK WITH REFERENCE TO SPATIAL MODELS OF URBAN TOURISM SPACE}

Discussion of tourism space has numerous concepts associated with it. The author in this article has taken into account the one developed by S. LISZEWSKI (1995) and that of B. WŁODARCZYK (2011).

S. LISZEWSKI was one of the first researchers to develop a classification for the division of tourism space (1995), taking into account such elements as tourism intensity, tourism development, tourism function and the impact of tourism on the condition of the natural environment (Table 1).

On this basis, he distinguished such types of tourism space as exploration, penetration, colonization, urbanization and assimilation. This is universal because it applies to all tourism spaces, not only urban ones.
This concept applied in relation to the tourism space of Barlinek to show an unambiguous indication of its type is not an easy task. Currently it is partly a space for tourism penetration and partly a space for colonization. Some elements, such as tourism development, allow it to be considered a colonization space, but the tourism intensity is relatively low. The author's research has shown that in the future, Barlinek's tourism space could become a space for colonization. Assimilation is also found, characterized mainly by the different roles tourists have in consuming space. Tourists are above all guests, occupying existing habitats, or using the services of summer and agritourism lodgings. They often visit their families and friends, and relations between tourists and residents are less formal (WŁODARCZYK 2009). In fact, in the case of Barlinek, a large number of tourists come just to visit family or friends (Fig. 2). This fact makes it possible to talk about an area of tourism assimilation based more on the relationship between tourists and residents than aspects closely related to the state of tourism infrastructure.

B. WŁODARCZYK (2011) developed a model layout of urban tourism space. In this work, he distinguished places generating tourism, reception destinations for tourism, and so-called 'transit settlements'. The author's research and observations have shown that Barlinek can be classified as a reception town for tourists and a 'transit' town (Fig. 5).

This was reflected in the responses given by tourists during the survey. Most, as their main motive for visiting Barlinek, indicated leisure or visits to family and friends (Fig. 5). Analysis of length of stay showed that almost half spend less than six hours in Barlinek (Fig. 6) which shows that for many the town is a stopping point on a longer journey.

B. WŁODARCZYK (2011) assumed that urban tourism space consists of such elements as town borders, spatial layout, various barriers, elements of tourism infrastructure and tourist attractions of a point, line or area nature (Fig. 7).

Table 1. S. Liszewski's characteristic types of tourism space

\begin{tabular}{|l|c|c|c|c|}
\hline \multirow{2}{*}{ Type of space } & \multicolumn{4}{|c|}{ Characteristic features } \\
\cline { 2 - 5 } & $\begin{array}{c}\text { tourism } \\
\text { intensity }\end{array}$ & $\begin{array}{c}\text { tourism } \\
\text { development }\end{array}$ & $\begin{array}{c}\text { main tourism } \\
\text { function }\end{array}$ & $\begin{array}{c}\text { impact of tourism on the natural } \\
\text { environment }\end{array}$ \\
\hline Exploration & minimal & lacking & cognitive & harmless \\
\hline Penetration & variable from small to mass & little & cognitive and leisure & not important \\
\hline Assimilation & medium & medium & leisure and cognitive & transforming (harmful) \\
\hline Colonization & large & large & leisure & degrading \\
\hline Urbanization & medium & large & residential & \\
\hline
\end{tabular}

Source: S. LISZEWSKI (1995, p. 99). 

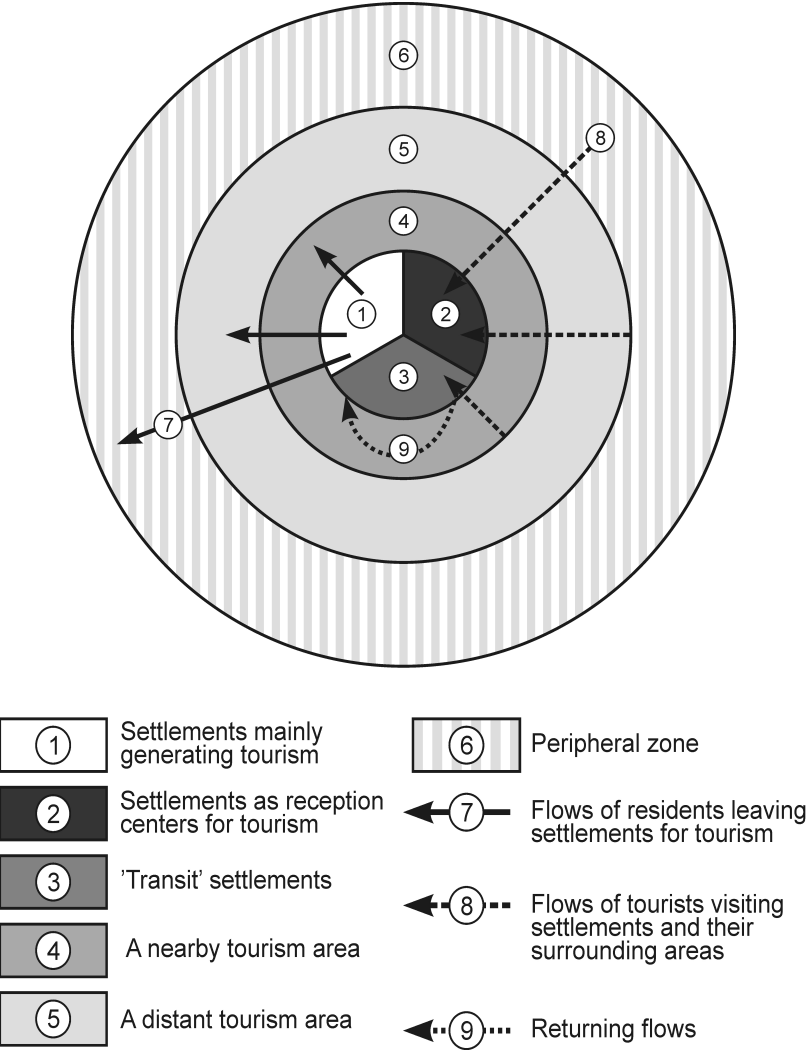

Fig. 5. Barlinek in the model of urban tourism space Source: author, based on B. WŁODARCZYK (2011)

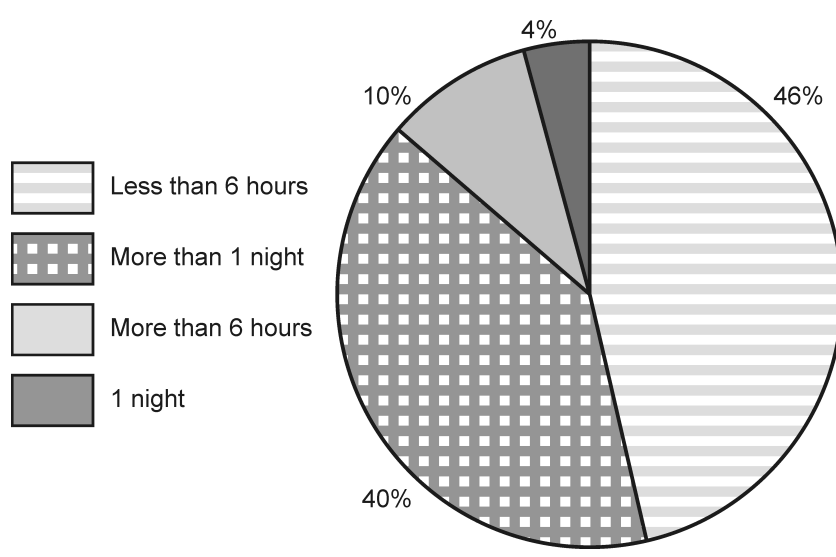

Fig. 6. Length of stay of surveyed tourists Source: author, based on surveys conducted in July 2017

Analysis of these elements makes it possible to distinguish different types of settlements due to characteristics of their tourism space. In this way B. WŁODARCZYK (2011) distinguished non-tourism settlements (without tourism space), a continuous tourism urban space, a settlement with a discountinous tourism space (parts of urban areas not attractive in terms of tourism) and a settlement with several tourism space enclaves (only some areas are attractive for tourists). The tourism

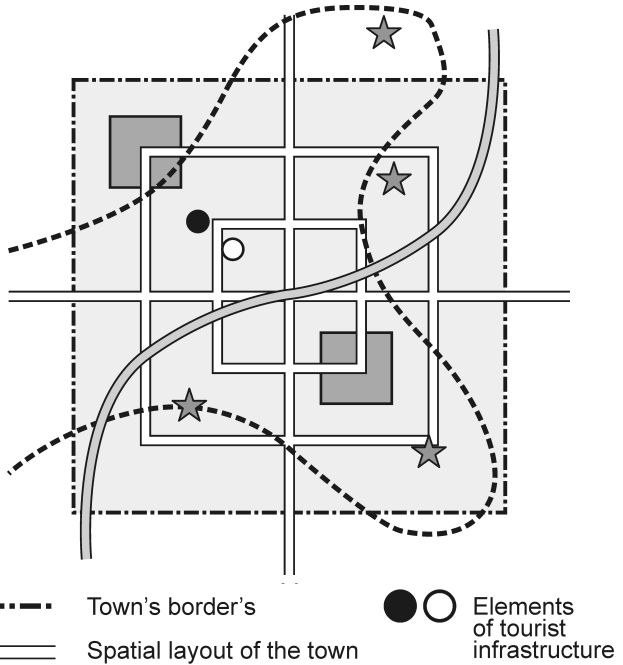

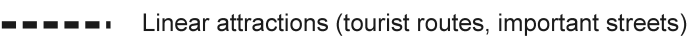

Area attractions

Point attractions (individual objects)

Barriers (rivers, borders)

Fig. 7. Elements that create urban tourism space Source: author, based on B. WŁODARCZYK (2011, p. 113)

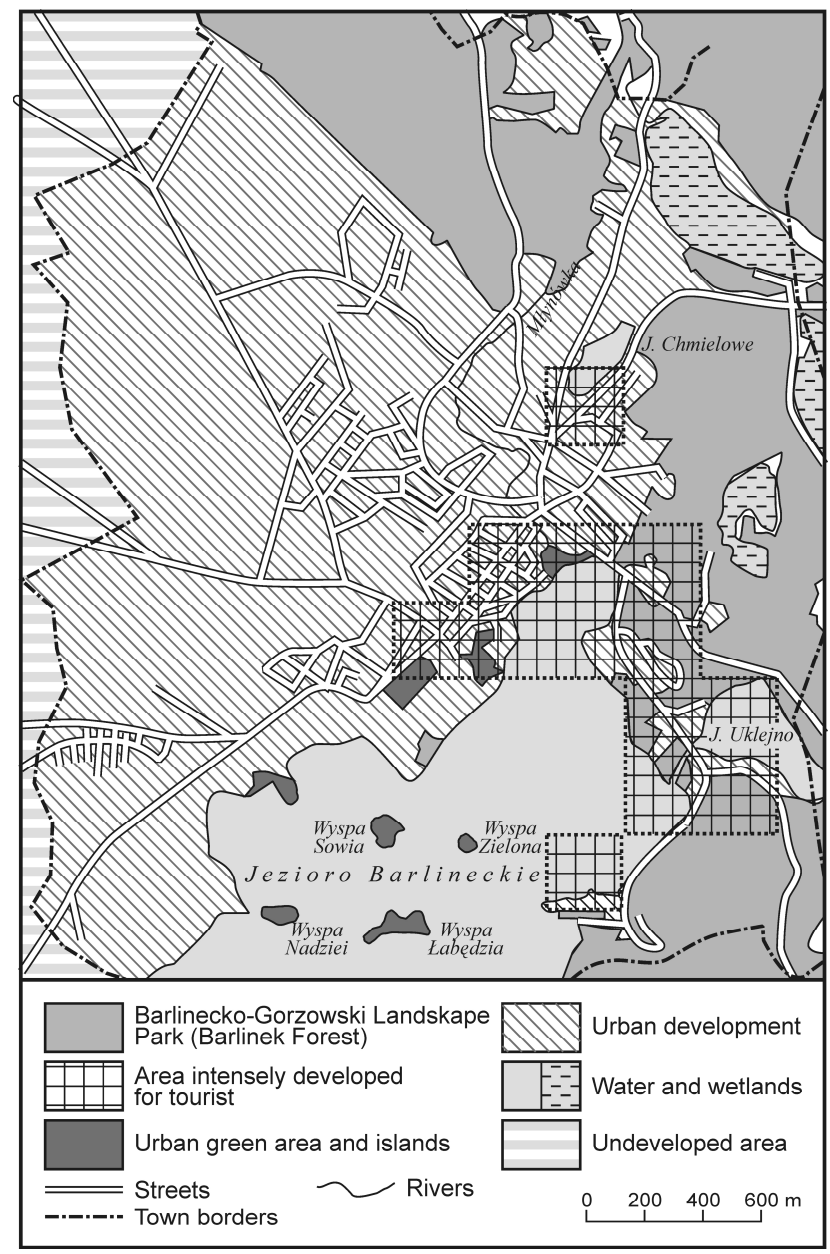

Fig. 8. Areas of Barlinek intensively developed for tourists Source: author, based on https://www.barlinek24.pl/... and http://www.geoportal.gov.pl/ 
space of Barlinek in discontinuous and perforated (Fig. 9). The most attractive areas, with the most intensively developed tourism infrastructure, are located in the center and on the north-west shores of the Lake Barlineckie (Fig. 8).

On the basis of the relationship between the elements several other tourism models have been distinguished. In preparing this article, the author developed a map of Barlinek, on which he replaced all these elements (Fig. 8) and could classify the tourism space of Barlinek for all models developed by B. WŁODARCZYK (2011).

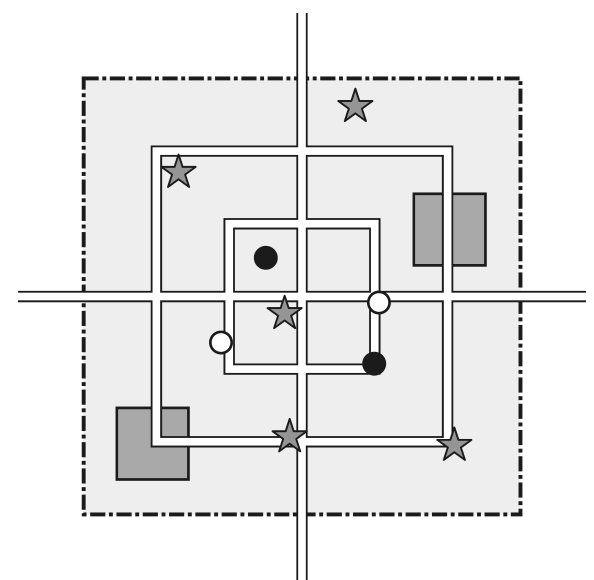

Fig. 9. A town with a discontinuous (perforated) tourism space Source: B. WŁODARCZYK (2011, p. 113)

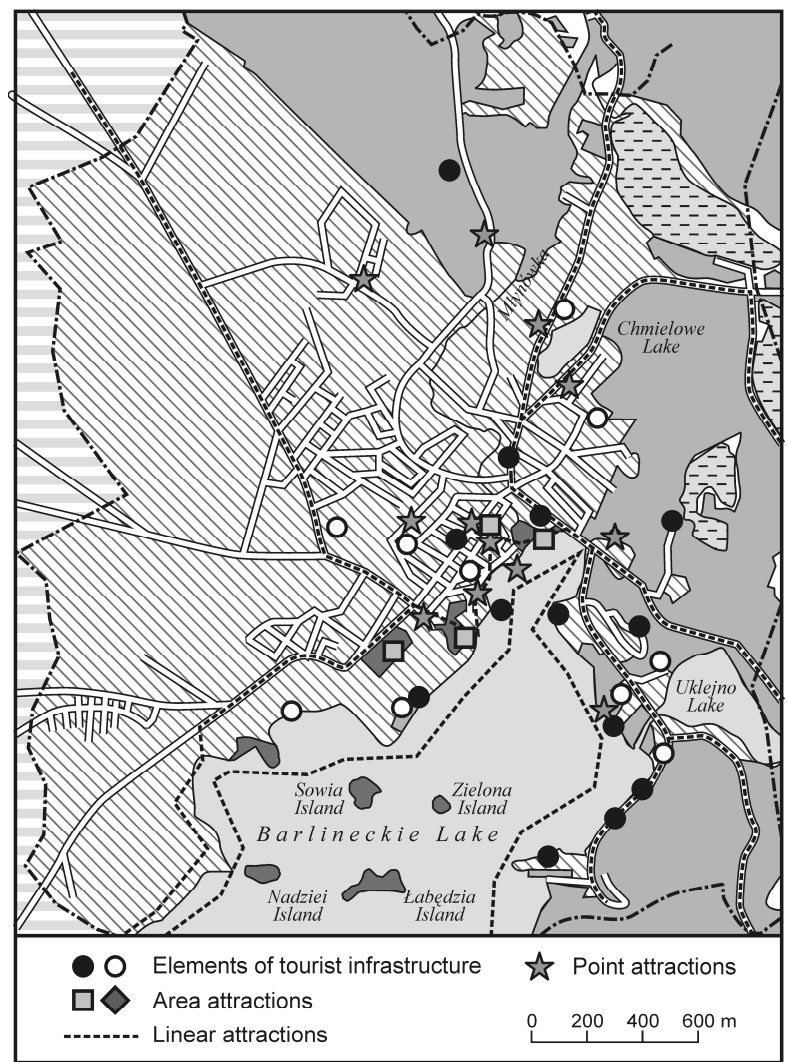

Fig. 10. Elements of Barlinek's urban tourism space Source: author based on https:/ / www.barlinek24.pl/... and http://www.geoportal.gov.pl/
Due to the character, scale and relative location of the elements, B. WŁODARCZYK (2011) distinguished settlements with one leading tourism attraction, with a polycentric tourism space, 'band-node' type and a town with a developed tourism attraction. Barlinek's example showed that it can be described as a town with a 'band-node' character (Fig. 11), because all tourism atractions and elements of tourism infrastructure are nodes interconnected by 'bands' in the form of communication routes and tourism routes.

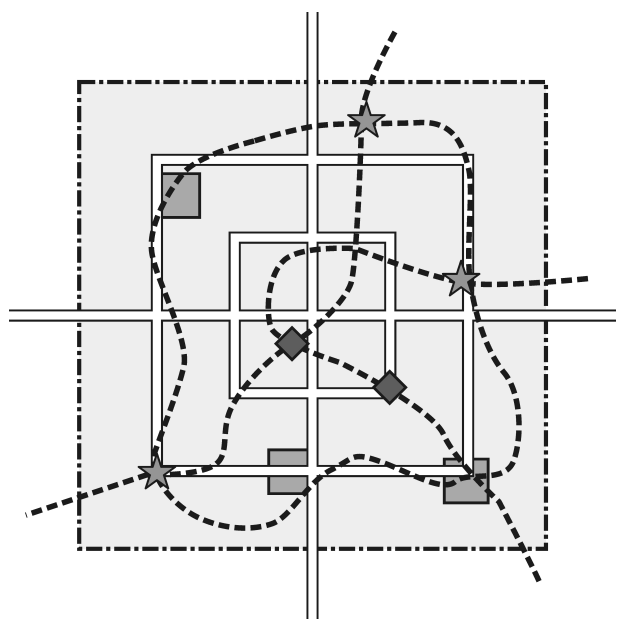

Fig. 11. A settlement with 'band-node' tourism space Source: B. WŁODARCZYK (2011, p. 113)

Another criterion determining the character of urban tourism space is the location of tourism attractions within a settlement. In this case, those where they are located centrally and those in which they are located peripherally were distinguished (WŁODARCZYK 2011). After analyzing the tourism space of Barlinek, it was found that the majority of attractions are located in the town center (Fig. 10) with such as the market square or Lake Barlineckie (Fig. 12). The fact, that Lake Barlineckie is Barlinek's leading tourism attraction was confirmed by both inhabitants and tourists (Fig. 12).

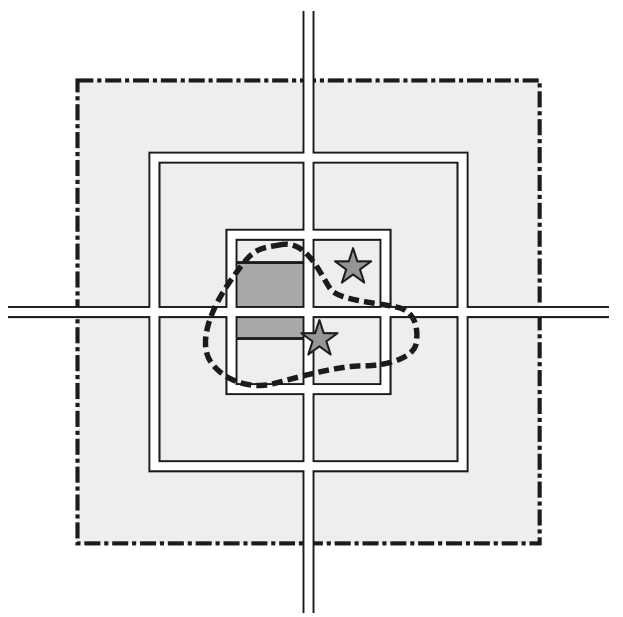

Fig. 12. A settlement with centrally located tourism attractions Source: B. WŁODARCZYK (2011, p. 113) 
Tourism attractions and their significance have also made it possible to distinguish settlements in which there is a domination of one attraction or where attractions are of equal importance. In Barlinek there was a clear domination of Lake Barlineckie as the main tourism attraction (Fig. 13).

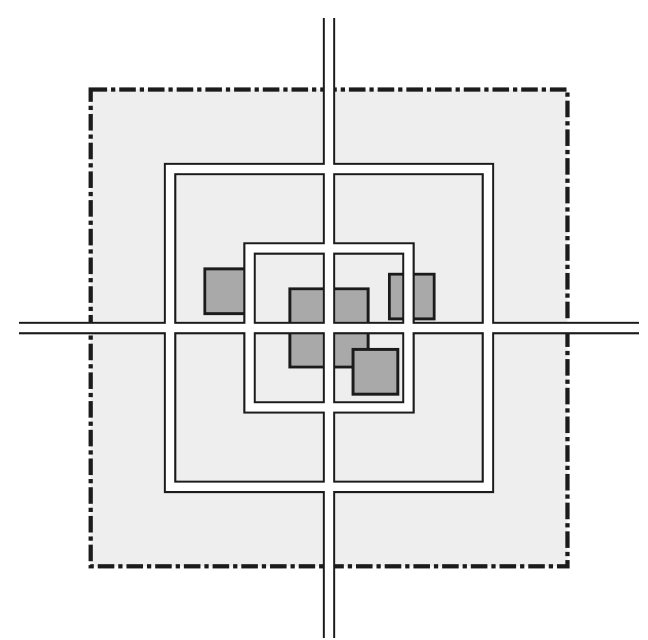

Fig. 13. A settlement with one leading attraction in its tourism space

Source: B. WŁODARCZYK (2011, p. 113)

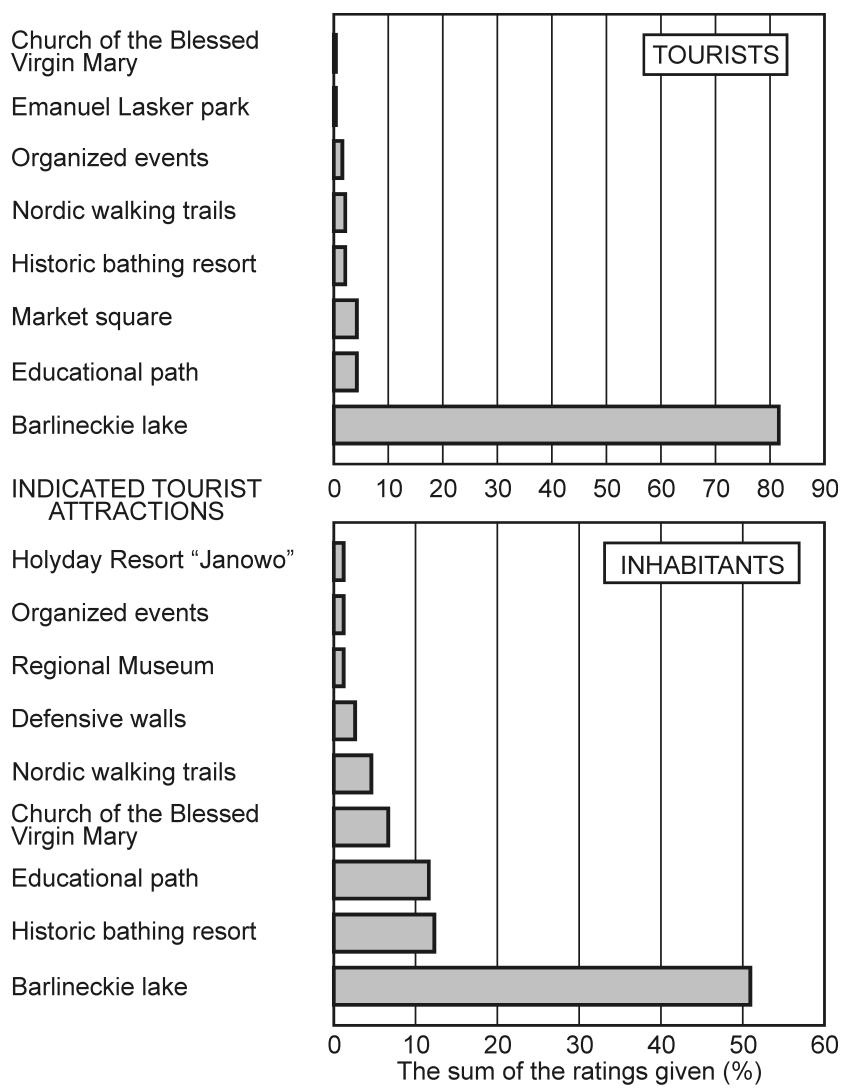

Fig. 14. The main tourism attractions of Barlinek in the opinion of tourists and inhabitants Source: author, based on surveys conducted in July 2017
The dominance of Lake Barlineckie in particular was evident among the surveyed tourists, indicated by as many as $80 \%$ of respondents. In the case of residents, Lake Barlineckie was indicated by slightly more than half of the respondents (Fig. 14).

The last of the criteria determining the character of urban tourism space is the direct relationship between the elements shaping this space, such as the relationship between tourism attractions and tourism infrastructure. Bearing in mind these dependencies, B. WŁODARCZYK (2011) distinguished settlements where tourism space is determined mainly by tourism attractions, settlements where tourism infrastructure determines the character, and those where both these elements are found (Fig. 15). In the urban tourism space of Barlinek its character is determined by elements of tourism infrastructure (Figs 10 and 15). This fact is confirmed by the diagram drawn by the author concerning the elements shaping the tourism space of Barlinek. The town has both a rich natural and cultural heritage as well as an extensive tourism infrastructure (Fig. 10).

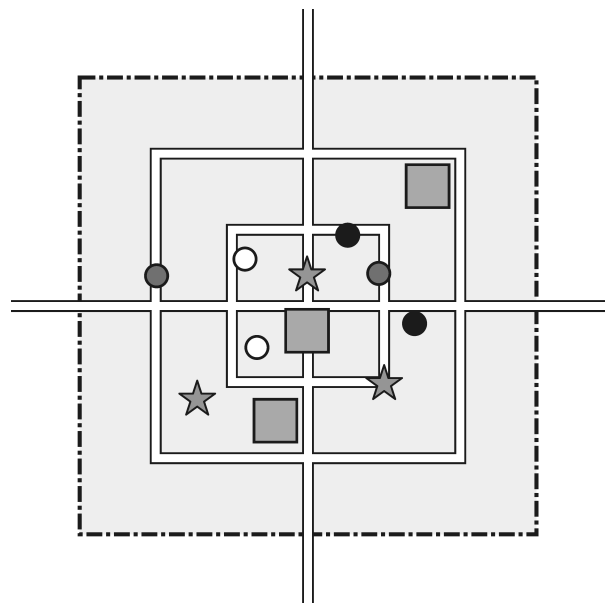

Fig. 15. The model of a settlement in which tourist attractions are determined by the tourism infrastructure Source: B. WŁODARCZYK (2011, p. 116)

\section{EXTENDED SWOT ANALYSIS OF BARLINEK TOURISM SPACE}

After collecting all materials and carrying out field studies, an extensive SWOT analysis of the tourism space of Barlinek was prepared. This analysis, like other SWOT analyses, is of a subjective nature as the author assigns scores and weights to individual aspects according to observations (Tables 2-5). All elements creating tourism space were taken into account, as well as all the conclusions obtained in surveys with residents and tourists. Performing such an analysis makes it possible to precisely determine the state of tourism in Barlinek in July 2017, as well as to determine opportunities for its development. 
Table 2. Extended SWOT analysis of Barlinek's tourism space: strengths

\begin{tabular}{|c|c|c|c|}
\hline \multicolumn{4}{|l|}{ Strengths } \\
\hline Internal factors & Weight & Rating & Weighted average \\
\hline Convenient geographical location (by three lakes, on the edge of the Barlinek Forest & 0.20 & 5 & 1.00 \\
\hline Favorable microclimate (higher than average annual air temperature, low precipitation) & 0.15 & 5 & 0.75 \\
\hline Good condition of water in Lake Barlineckie & 0.15 & 4.5 & 0.675 \\
\hline Barlinek promoted as the 'European Nordic Walking Capital' & 0.10 & 4.5 & 0.45 \\
\hline $\begin{array}{l}\text { Many types of tourism routes (nordic walking, walking, cycling, water routes, thematic } \\
\text { routes) }\end{array}$ & 0.10 & 4.5 & 0.45 \\
\hline $\begin{array}{l}\text { Occurrence of historic buildings from various historical periods (the Middle Ages and the turn } \\
\text { the } 20^{\text {th }} \text { century) }\end{array}$ & 0.05 & 4.5 & 0.225 \\
\hline A large variety of accommodation facilities & 0.05 & 4 & 0.20 \\
\hline A large number of gastronomy facilities & 0.05 & 4 & 0.20 \\
\hline A well-developed paratourism base & 0.05 & 4 & 0.20 \\
\hline Organization of many cultural and sport events & 0.05 & 3 & 0.15 \\
\hline Functioning of many tourism products like 'Queen of Barlinek Forest' or 'Blue Legend Trail' & 0.05 & 3 & 0.15 \\
\hline Total & 1.00 & - & 4.45 \\
\hline
\end{tabular}

Source: author, based on a field inventory carried out in July 2017.

Table 3. Extended SWOT analysis of Barlinek's tourism space: weaknesses

\begin{tabular}{|c|c|c|c|}
\hline \multicolumn{4}{|l|}{ Weaknesses } \\
\hline External factors & Weight & Rating & Weighted average \\
\hline $\begin{array}{l}\text { Poor external transport accesibility (lack of railway infrastructure, negligible number of bus } \\
\text { connections with nearby towns }\end{array}$ & 0.30 & -3.0 & -0.90 \\
\hline Lack of tourism development around Lake Uklejno and Lake Chmielowe & 0.20 & -3.5 & -0.70 \\
\hline Limited access to the shoreline of the Lake Barlineckie & 0.20 & -3.5 & -0.70 \\
\hline Poor ratings for the town's promotion & 0.05 & -3.5 & -0.175 \\
\hline Well-developed industry to the north and north-west of the town & 0.05 & -3.5 & -0.175 \\
\hline Large differences in height between the southern and northern parts of the town & 0.05 & -4.0 & -0.20 \\
\hline Systematic decrease in the number of inhabitants & 0.05 & -4.0 & -0.20 \\
\hline Emigration of young inhabitants abroad & 0.05 & -4.0 & -0.20 \\
\hline A small number of parking spaces & 0.05 & -5.0 & -0.25 \\
\hline Total & 1.00 & - & -3.50 \\
\hline
\end{tabular}

Source: author, based on a field inventory carried out in July 2017.

Table 4. Extended SWOT analysis of Barlinek's tourism space: opportunities

\begin{tabular}{|l|c|c|c|}
\hline \multicolumn{1}{|c|}{ Chances } \\
\hline \multicolumn{1}{|c|}{ Internal factors } & Weight & Rating & Weighted average \\
\hline The growing popularity of tourism and the recreational activity of nordic walking & 0.30 & 5 & 1.50 \\
\hline The growing popularity of weekend trips from large towns and cities & 0.20 & 4.5 & 0.90 \\
\hline Positive ratings in the opinion of the majority of inhabtants & 0.20 & 4 & 0.80 \\
\hline Friendly relations between tourists and inhabitants & 0.10 & 4 & 0.40 \\
\hline Barlinek's growing cooperation with foreign partner settlements & 0.10 & 3 & 0.30 \\
\hline A better state of tourism development compared to neighboring towns & 0.05 & 3 & 0.15 \\
\hline The growing activity of the town at trade fairs and exhibitions & 0.05 & 2 & 0.10 \\
\hline Total & $\mathbf{1 . 0 0}$ & - & $\mathbf{4 . 1 5}$ \\
\hline
\end{tabular}

Source: author, based on a field inventory carried out in July 2017. 
Table. 5. Extended SWOT analysis of Barlinek's tourism space: threats

\begin{tabular}{|l|c|c|c|}
\hline \multicolumn{1}{|c|}{ Threats } & Weight & Rating & Weighted average \\
\hline \multicolumn{1}{|c|}{ External factors } & 0.25 & -2.0 & -0.50 \\
\hline Competition from other tourism lake districts, in particular the Mazurian & 0.25 & -2.0 & -0.50 \\
\hline Low popularity of the town nationally & 0.2 & -3.0 & -0.60 \\
\hline Lack of railway infrastructure and rail connections & 0.2 & -3.0 & -0.60 \\
\hline A small number of PKS bus conenctions with other towns & 0.05 & -4.5 & -0.225 \\
\hline $\begin{array}{l}\text { Difficulties in cooperation with Gorzów Wielkopolski due to location in separate } \\
\text { voivodeships }\end{array}$ & 0.05 & -5.0 & -0.25 \\
\hline Low popularity of organized events (known only on a local scale) & $\mathbf{1 . 0 0}$ & - & -2.675 \\
\hline Total & & - \\
\hline
\end{tabular}

Source: author, based on a field inventory carried out in July 2017.

After adding together the weighted averages of strengths and weaknesses, as well as opportunities and threats, the author put the figures into Cartesian coordinates (Fig. 16).

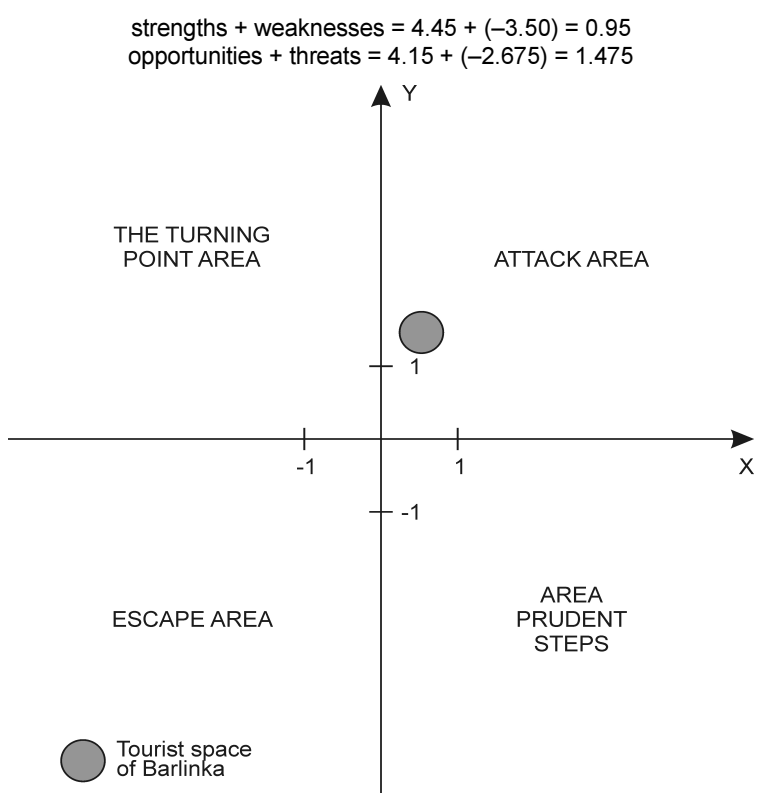

Fig. 16. The position of Barlinek's tourism space after an extended SWOT analysis

Source: author, based on an extended SWOT analysis

The SWOT analysis carried out showed that Barlinek is located in a field called an 'attack area'. This means that this tourism space has a lot of possibilities, thanks to which it can use all its numerous advantages and in the future take on larger groups of tourists. Moreover Barlinek should adopt an aggressive development strategy (the so-called 'maxi-maxi'). In realization of this strategy, it will be the task of the town authorities to strive to make the best use of opportunities emerging, as well as relying on their own strengths.

\section{SUMMARY}

After conducting an analysis of Barlinek's tourism space and classyfying it terms of spatial models, a number of conclusions were formulated. First of all, the tourism space of Barlinek does not cover the whole area of the town being located in its central part, and on the north-west, north and north-east shores of the Barlineckie Lake.

In the context of the model of urban tourism space developed by B. WŁODARCZYK (2011), it was concluded that it has a non-continuous (perforated), 'band-node' character, created by tourism attractions and elements of tourism infrastructure. Among the attractions, Lake Barlineckie is clearly dominant. It is this which is considered by most tourists and inhabitants to be the main attraction of the town and constituting a kind of Barlinek 'business card'.

According to the types of tourism space developed by S. LISZEWSKI (1995), it is partly a space for tourism penetration and partly a space for tourism colonization. Its unambiguous classification is a difficult task, but due to further development in the near future it can become fully a space of tourism colonization.

Most often Barlinek is a destination for tourists, especially for nordic walking. Sometimes, however, it is a 'transit' point, especially for those coming here to visit family or friends.

The extended SWOT analysis of Barlinek's tourism space has shown that it can still develop in territorial, quantitative and qualitative aspects. In addition, the state of the tourism infrastructure, especially the paratourism base, makes it fully adapted to variuous forms of tourism. Most extensively, active tourism and nordic walking are already found while water tourism and cycling are also possible. 


\section{BIBLIOGRAPHY}

Aktywny wypoczynek w Barlinku Aktive Erholung in Barlinek, Centrum Informacji Turystycznej - BOK, 2017, ZAPOL Sobczyk s.j., Szczecin.

BORYCZKA J., STOPA-BORYCZKA M., 2005, Klimat, [in:] K. Ostaszewska, A. Richling (eds.), Geografia fizyczna Polski, Wydawnictwo Naukowe PWN SA, Warszawa, pp. 114-116.

CZOPEK L., PIESZCZACHOWICZ J., 2001, Popularna encyklopedia powszechna, vol. 2, Grupa Wydawnicza Bertelsmann Media, Warszawa.

HOFFMAN K., 2014, Szlakiem Szachowego Mistrza Świata Emanuela Laskera, Studio CD, Gorzów Wielkopolski.

HUSBANDS W.C., 1983, Tourists space and tourist attraction, an analysis of the destination choices of European travelers, Leisure Sciences, 5, 4, pp. 289-307.

JACKOWSKI A., WARSZYŃSKA J., 1978, Podstawy geografii turyzmu, Państwowe Wydawnictwo Naukowe, Warszawa.

KACZMAREK J., STASIAK A., WŁODARCZYK B., 2010, Produkt turystyczny - pomyst, organizacja, zarządzanie, Polskie Wydawnictwo Ekonomiczne, Warszawa.

KONDRACKI J., 1998, Geografia regionalna Polski, Wydawnictwo Naukowe PWN, Warszawa.

KUREK W., MiKA M., 2008, Pojęcia podstawowe, [in:] W. Kurek (ed.), Turystyka, Wydawnictwo Naukowe PWN, Warszawa, pp. 24-27.

LISZEWSKI S., 1995, Przestrzeń turystyczna, „Turyzm”, 5, 2, pp. 87-103.
MielCAREK K., 2006, Barlinek. 60 Lat Parafii pw. Niepokalanego Serca Najświętszej Maryi Panny, PPH ZAPOL Dmochowski, Sobczyk s.j., Szczecin.

MielCAREK K., PRZYBYLSKI G., 2009, Wodna Ścieżka Przyrodnicza na Jeziorze Barlineckim, Studio CD, Gorzów Wielkopolski.

MiossEC J.M., 1976, Elements pour une teorie de l'espace touristique, Centre des Hautes Etudes Touristiques, C, 36 [BB1], pp. $41-48$.

PRZYBYLSKI G., SKAZIŃSKI B., 2014, Dzieje Barlinka, [in:] B. Skaziński (ed.), Barlinek na szlaku młynów, Wyd. ZAPOL, Szczecin, pp. 27-44.

STALSKI M., 1984, Użytkowanie ziemi w turystyce, Przegląd Zagranicznej Literatury Geograficznej, 2, pp. 139-148.

Ustawa z dnia 29 sierpnia 1997 r. o ustugach turystycznych, o ustugach hotelarskich oraz ustugach pilotów wycieczek i przewodników turystycznych, 1977, DzU, nr 13, poz. 884.

WŁODARCZYK B., 2009, Przestrzeń turystyczna - istota, koncepcje, determinanty rozwoju, Wydawnictwo Uniwersytetu Łódzkiego, Łódź.

WŁODARCZYK B., 2011, Miasto i przestrzeń turystyczna, [in:] B. Włodarczyk (ed.), Turystyka. Księga jubileuszowa w 70. rocznice urodzin profesora Stanistawa Liszewskiego, Wydawnictwo Uniwersytetu Łódzkiego, Łódź, pp. 105-120.

https://www.barlinek24.pl/images/stories/plan_miasta_d.jpg; 2.05.2018

http://www.geoportal.gov.pl/; 30.05.2018.
Article received: 17 October 2018 Accepted:

29 November 2018 